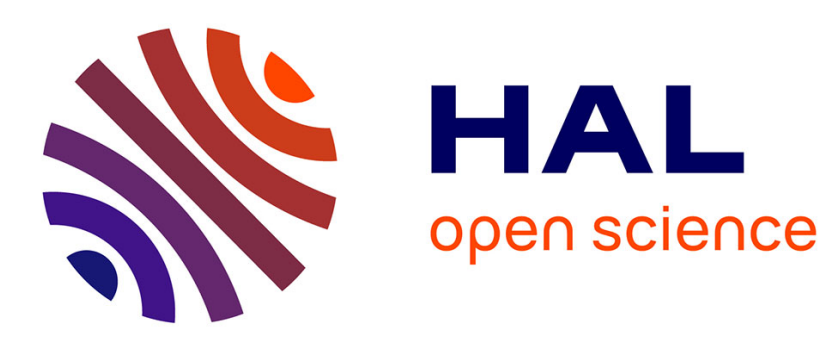

\title{
Identities and ideals: Psychoanalytic dialogues of self and leadership
}

Gazi Islam

\section{To cite this version:}

Gazi Islam. Identities and ideals: Psychoanalytic dialogues of self and leadership. Leadership, 2014, 10 (3), pp.344-360. 10.1177/1742715013498404 . hal-00963539

\section{HAL Id: hal-00963539 \\ http://hal.grenoble-em.com/hal-00963539}

Submitted on 21 Mar 2014

HAL is a multi-disciplinary open access archive for the deposit and dissemination of scientific research documents, whether they are published or not. The documents may come from teaching and research institutions in France or abroad, or from public or private research centers.
L'archive ouverte pluridisciplinaire HAL, est destinée au dépôt et à la diffusion de documents scientifiques de niveau recherche, publiés ou non, émanant des établissements d'enseignement et de recherche français ou étrangers, des laboratoires publics ou privés. 
running head: Psychoanalytic Dialogues of Identity and Leadership

Identities and Ideals: Psychoanalytic Dialogues of Self and Leadership

\section{Gazi Islam}

Associate Professor, Grenoble Ecole de Management

12 Rue Pierre Semard

38000 Grenoble

France

Fax. 330476706253 


\begin{abstract}
The author contextualizes recent developments in socio-cognitive approaches to leadership by drawing on psychoanalytic conceptions of self-identity. It is argued that psychoanalytic views of the self are complementary to contemporary social-cognitive approaches, although historical divergences in these literatures have impeded mutual dialogue. This initiative at dialogue examines charismatic, schema, and self- identity theories of leadership within a psychoanalytic framework, arguing that when self-identity is viewed broadly, convergences between these approaches become apparent. A broad view of the self makes notions of authority central to the construction of personal identities, underscores the ambivalence and relationality of self-processes, and highlights the normative assumptions underlying followership that may be difficult to theorize with contemporary socio-cognitive approaches.
\end{abstract}

Key words: identity, charisma, leadership, self-concept 
Identities and Ideals: Psychoanalytic Dialogues of Self and Leadership

Recent leadership literature has taken a social-cognitive turn, giving increased importance to followers' cognitive prototypes of leaders, as well as self-identities. (e.g. Lord \& Brown, 2004; 2001; Hogg, 2005; 2001; Hogg \& van Knippenberg, 2003). While these approaches run parallel to more traditional trait and behavioral approaches (e.g. Zaccaro, 2007; Judge, Bono, Ilies \& Gerhardt, 2002), social-cognitive views emphasize follower-based theories of leadership categorization and identification (e.g. Lord \& Maher, 1991; Hogg, 2001). This new emphasis has opened the leadership literature to questions concerning the complex psychological processes leading people to recognize leaders and to follow those who come to embody leadership attributes.

While these developments have contributed to our knowledge about leader perceptions, several important leadership phenomena remain difficult to explain in the sociocognitive paradigm. For example, as elaborated further in this paper, the link between categorizing people as leaders and investing them with moral authority, the connection between identification with leaders and normatively-laden self appraisals, and the mystery of why people would be emotionally connected to leaders in the first place, seem difficult to explain within the socio-cognitive paradigm. I argue that psychoanalytic approaches to followership, which stress identification and idealization, provide both a complement to and a critique of contemporary socio-cognitive approaches. Specifically, using insights into the selfother relation that psychoanalysis provides vis a vis socio-cognitive approaches, psychoanalysis provides a critique of these approaches. These insights, in turn, create avenues for future research that are not exclusive, but complementary to, socio-cognitive approaches. 
Psychoanalytic perspectives have been largely absent from discussions of follower identity and social cognition, although these perspectives have had much to say about follower cognitions (Cluley, 2008). Within leadership thought more broadly, psychoanalysis, in its diverse forms ${ }^{\mathrm{i}}$, has generated an active stream of ideas, from its early roots at the Tavistock group (e.g. Bion, 1961) to more contemporary discussions of leadership and projection (e.g. Kets de Vries, 1989), corporate corruption (e.g. Stein, 2007), group dynamics (e.g. Long, 1991; Goethals, 2005), subordinate status (e.g. Oglensky, 1995), neurosis (Kets De Vries and Miller, 1985) and transference (e.g. Diamond \& Allcorn, 2003). Some have recognized that an identity focus in leadership allows convergence with psychoanalysis, (e.g. Goethals, 2005), but much work remains in establishing the main points of such a convergence.

I argue that psychoanalysis can inform theoretical lacunae created by social cognitive views of follower perceptions, particularly those based around identity theories. First, the centrality of authority figures to identity formation in psychoanalysis allows the link between leader prototypicality and leader identification to be more richly theorized than is currently the case. Second, while socio-cognitive views of identity often stress the unity or cohesiveness of self-schemas (e.g. Hogg 2001; Albert \& Whetten, 1985), psychoanalytic approaches emphasize the relationality of the self, better explaining normative aspects of the self and as well as the idealization of leaders. Third, because identity in psychoanalysis is linked to the super-ego, an idealizing, judging faculty, the moral pressures that leaders represent and exert on followers can be better explained through this lens.

The argument of the paper will unfold as follows: First, I briefly describe how socialcognition has emerged as an important leadership paradigm, leading to increased focus on follower-based views. I argue that this emergence has meant that identity, in particular, has become increasingly central to understanding leadership (e.g. Hogg, 2005; 2001). Next, 
drawing upon psychoanalysis (e.g. Freud, 1914, 1921), I examine how notions of identity as primary and secondary narcissism (Freud, 1914; c.f. Cluley, 2008) impact claims made by socio-cognitive theorists, primarily through the replacement of an ego-centric with a relational conception of self-identity. Next, I apply this relational conception to socio-cognitive views, discussing the theoretical implications of applying psychoanalysis to social-cognitive theories of leadership. Finally, I highlight the contributions of this application, which include a.) a better understanding of the idealization of leaders as objects of identification, b.) a way of understanding such identification as also ambivalent, reflecting a multi-layered conception of the self, and c.) a way to understand how leaders do not only mobilize interpersonal attraction but also exert a moral, normative force

\section{Leader Prototypes and Follower Self-Concepts}

Socio-cognitive views of leadership hold that leadership is based in categorization processes (e.g. Lord \& Maher, 1991), involving leader and self-identities. In contrast to earlier top-down, romanticized (e.g. Meindl, 1993) theories of leadership, social-cognitive views tend to replace charismatic leadership notions with empirical issues of leader-follower fit. Rather than a focus on the person of the leader (e.g. Zaccaro, 2007; Judge, et al, 2002) these views focus on follower aspects, with an emphasis on follower cognition (e.g. Lord \& Brown, 2004; 2001). The focus on followers, rather than leaders themselves, responds to a key question: How is it that individuals come to embody models of authority for others, and how is it that others successfully internalize such models? On what psychological foundations can we theorize a bridge between authority and subjectivity?

From early critiques of approaches emphasizing the traits and behaviors of leaders (esp. Stogdill, 1948), scholars increasingly focused on relational and follower aspects, taking leadership to be founded upon leader-follower interactions (e.g. Tyler \& Lind, 1992; Graen, 2007). Beginning with exchange theories (Graen \& Uhl-Bien, 1995), this focus further shifted 
toward followers, increasingly emphasizing followers' mental states (Lord \& Maher, 1991; Lord, Foti \& DeVader, 1984). These studies used the notion of cognitive prototypes (Rosch, 1978) to describe how organizational members organize and classify views of leaders. Prototype theories took two main forms, the earlier leadership categorization theory (LCT; Lord, 1977, 1985; Lord, Foti \& Phillips, 1982; Lord et al, 1984), followed by self-concept based approaches (van Knippenberg, van Knippenberg, De Cremer \& Hogg, 2004), most notably, the social identity theory of leadership (SIT-L; Hogg, 2001; Hogg \& Terry, 2000). While LCT examined followers' mental prototypes of leaders (Lord et al, 1984), SIT-L insisted that leader schemas were not independent of, but rather intimately connected to, selfidentities, or follower's schematized views of themselves (Hogg, 2001; Hogg \& Terry, 2000). Nevertheless, both retained a strong focus on cognitive processes, as well as a follower focus.

The shift to follower-based cognitive views, based on cognition (and more specifically, categorization) research (Lord, 1977,1985; Lord et al., 1984 ; Lord, et al, 1982; Nye \& Forsyth, 1991) framed leadership as a knowledge structure in the minds of followers, focusing on the alignment of implicit leadership or self-identity categories with leader qualities (for a meta-analytic review of LCT, see Lord, DeVader \& Alliger, 1986). This shift to follower cognitions makes sense in light of various empirical developments, for example, the finding that inspirational leaders often impact subjective perceptions more than they impact objective performance (Lowe, Kroeck, and Sivasubramaniam 1996), that performance affects leadership evaluations more than the converse (e.g. Agle, Nagarajan, Sonnenfeld \& Srinivasan, 2006), and that cognitive biases such as the fundamental attribution error can explain leadership perceptions (e.g. Pfeffer, 1981). LCT and SIT-L shifted the theoretical terrain by viewing inspirational leaders in terms of cognitive structures to be studied in terms of perceptual, memory and attribution processes on the part of followers, enriching the 
potential of studying leadership as a properly psychological phenomenon on the part of followers (e.g. Lord \& Maher, 1991).

According to LCT, leadership attributions involve relatively simple categorizations (leader/non-leader or leader/follower) of people into preexisting hierarchically oriented categories (Foti, Fraser \& Lord, 1982, p. 326). While reframing leadership as a primarily cognitive phenomenon opened up the black box of individual trait approaches, it nevertheless privileged cold processes of cognitive processing over hot processes of emotion, motivation and moral intuition, processes that we now know affect social judgment making (e.g. Haidt, 2001). For example, contemporary research has demonstrated the importance of affect transfer in leadership (Bono \& Ilies, 2008; Erez et al, 2008) and attempts to link social psychology with ethics are increasing (e.g. Arjoon, 2008). Given the emotional and normative salience of leadership cognition, it is unlikely that leadership attributions would be made purely on the basis of a prototype matching process, a point which Erez et al. (2005) emphasize.

The emergence of identity-based leadership theories provided a potential solution to the problem of emotion and normative processes in prototype matching. As emotionally laden and intimate (e.g. Beer \& Keltner, 2004) self-concepts could potentially explain the emotional and value bases of leadership on the part of followers. While identity theorists have called for more research as to the relational and interpersonal implications of identity in leadership (e.g. van Knippenberg et al, 2004), these aspects remain largely subordinate to cognitive classificatory mechanisms.

To understand why such discussions were relatively limited, we may note that the view of self-identities espoused by SIT-L focused on a particular brand of social identity theory called self-categorization theory (e.g. Turner, 1985), which emphasized epistemic versus self-esteem based identity motives. Whereas Tajfel \& Turner's (e.g. 1979) original 
formulation of social identity theory privileged group-based self-esteem mechanisms, selfcategorization theory emphasized uncertainty avoidance (Hogg \& Terry 2000), a selfverification motive referring to the need to build a coherent self-view. This epistemic view of the self is a common feature of schema-based views of the self (e.g. Khilstrom, Beer \& Klein, 2003; Khilstrom \& Klein, 1994).

By focusing on epistemic coherence, such views tended to view followers as pursuing coherent identities, inconsistent with the psychoanalytic idea that identity involved affectively and normatively powerful images projected onto idealized others, and leading to identity investments in people other than the self. I suggest that while social identity approaches made an important insight in locating follower-based views in the identity structures of individuals, the way that identity was understood meant that much of the value of this insight was left unrealized. By focusing on verification-based views of the self, SIT-L approaches remove the emphasis on striving, replacing it with cognitive matching. In other words, while the selfenhancement perspective sees the self as motivated by a normative ideal, self-categorization theory tends to overlook this motivation, focusing more on self-coherence (Hogg \& Terry, 2000). It is precisely this coherence view of the self that psychoanalysis will problematize, as I describe below.

Psychoanalytic Selves, Social Cognition and the Leadership Role

Despite the infrequent dialogue between socio-cognitive and psychoanalytic approaches, the study of hierarchy, authority and leadership has been studied in terms of selfidentity and perception of leaders since Freud's Totem \& Taboo (1912-13) and Group Psychology and the Analysis of the Ego (Freud, 1921). Within this tradition, topics such as identity, authority, leader perceptions can be conceptualized in terms of the individual's selfdevelopment, a process linked to notions of narcissism (Freud, 1914). 
As the basic principles of self-development as a narcissistic process have been previously explored in the organizational literature (c.f. Schwartz, 1990; Cluley 2008), I will not elaborate on these principles here. A short summary, however, should be useful to readers unfamiliar with psychoanalysis. Briefly, this model posits that basic concepts of self and other are constructed from an affect-laden process by which desire for a lost sense of omnipotent unity with the world (referred to as primary narcissism), leads to a utopian image referred to as the ideal ego. Because this irrecuperable sense of unity proves impossible to achieve, the developing ego emerges in an attempt to replace the lost primary narcissistic object. This results in a secondary narcissism, establishing a substitute identity constituted by social roles and self-categories (referred to as the ego-ideal, a type of mental model of the self, Carr \& Lapp, 2005). The ego-ideal differs from the ideal ego in that the latter refers to an idealized striving for total connection, often by irrationally idealizing eminent others (Lagache, 1961), while the former arises when the narcissistic impulse leads the subject to adopt "realistic" self-identities (Mijolla-Mellor, 2005). The ego-ideal has thus been described as a project (Chasseguet-Smirgel, 1985, p.29) that the individual undertakes in a spirit of an autonomous aspiration (Blos, 1985, p38).

Such self-assertion, however, finds satisfaction only through pre-existing social models, involving injunctions and demands for obedience to identity norms. As a consequence, the normative element involved in the motivated project of the self can also involve a self-loathing, punishing function, the super-ego (Freud, 1933). The super-ego, unlike the ego, is not a rational adaptive capacity but a normative, desiring force, an expression of the internalized image of the demands of authority. Thus while the ego-ideal and the super-ego both lead to self concepts that are morally charged, the ego-ideal's standards are essentially aspirational, whereas the super-ego is censoring and self-punishing. Applying this short description to a socio-cognitive identity perspective, it is 
notable that ideal ego, ego-ideal and super-ego are all aspects of the individual's selfconstitution, and describe different aspects of this constitution, throwing into doubt theories that stress a unified notion of identity. More specifically, these constituents describe different moments in the attempt by individuals to negotiate their relation to an unyielding world. The ideal ego reflects the person's yearning for unity with a beloved primary connection, for Freud, the maternal object (e.g. Freud, 1905). The ego-ideal reflects the aspirational identities that the person self-consciously adopts in the hope of reaching this ideal. The super-ego reflects subjectivized authority relations by which the person punishes him/herself for the aloofness and failure that accompany this impossible task. This distinction can lead us to two complementary principles: First, that an examination of self-identity should take into account the dynamic strivings of the self towards an external object, and second, that describing authority involves examining how these relations depend on the subjective internalization of authority figures into the structure of the self.

With these two foundational ideas, it should be clear how follower-based sociocognitive perspectives can draw from psychoanalysis. These approaches do focus on the leader-follower relation, but because they lack a mechanism to articulate identity or cognition as relational and interpersonal, it is difficult to bridge the divide between leader cognition and self-identity. Psychoanalysis can help in this respect, because it views cognitive processes as fundamentally relational (c.f. Cluley, 2008). In the next section, I propose how a psychoanalytic conception of the self can help to think through identity and leadership cognition.

Based on this discussion, we can infer two key differences between psychoanalytic and socio-cognitive views of follower cognition. First, in psychoanalysis, identity is a dynamic and relational process that occurs between followers and leaders, as opposed to followers simply possessing distinct leader and self-schema. Second, identity involves forms 
of internalization from the outside, according to normative demands, which makes identity partial, emotional, and morally charged. We can thus specify a series of areas in which sociocognitive approaches can be re-imagined into incorporate the normative and relational aspects of leadership that would otherwise be difficult to explain.

Leaders as Idealized Self-Visions

The notion of idealization does appear in some psychological leadership literature. For example, authors in the "neo-charismatic" leadership tradition (e.g. Fiol, Harris \& House, 1999; Beyer, 1999) have suggested the importance leader idealization, as in Avolio's (1993) notion of idealized influence. However, idealization tended to be lost or "cognitivized" as they moved to the follower-based literature. For example, LCT examines leader prototypes, which are ideals in the sense of ideal-types or cognitive categories, but not in the emotionally and normatively loaded sense of "ideal" that one finds, for example, in notions of charisma (e.g. Beyer, 1999)

By contrast, idealization in relation to authority figures is central to the identityforming process described in psychoanalysis, and emphasizes both cognitive and normative bases of idealization. Using the notions of ideal ego, ego-ideal, and super-ego, idealized leaders may be thought of as projections of authority by followers. The follower, rather than simply perceiving the leader as imbued with special powers (e.g. House \& Beatz, 1979), derives vicarious empowerment from identification with the leader. As Freud (1921, p. 27) describes identification, rather than matching group categories with previous individual categories, people "lose the sense of the limits of their individuality". Leaders thus inspire followers not through demonstrating merit or excellence per se, but by embodying the possibility of achieving satisfaction, which orients the ego-struggles of followers.

Following Freud, this struggle takes diverse forms according to the nature of the narcissistic identification of the follower, a diversity which, to my knowledge, is unexplored 
in the organizational literature (although narcissism is discussed, see Cluley, 2008, Kets de Vries \& Miller, 1985). These forms are summarized in Table 1. In a primary narcissistic relation (Freud, 1914), the leader appears as a vision of perfection to be followed, an allencompassing good imbued with a gift of grace, a view harkening early descriptions of charisma (Weber, 1947). In a secondary narcissistic relation (Freud, 1914), the follower constructs a sense of identification with the leader as an aspirational target, in line with the ego-ideal. This relation seems somewhat similar to earlier versions of social identity theory, which focused on positive self-strivings (e.g. Tajfel \& Turner, 1979). Finally, in an Oedipal relation (e.g. Freud, 1933), the leader takes on a super-egoic function, wherein follower identification results in internalized authority relations and the subsequent guilt associated with being an unworthy subject, as inadequately embodying the symbolic demands of authority. This relation has received much less treatment in the literature, although some authors have touched upon it using Lacanian notions of symbolic indebtedness (e.g. Arnaud, 2002).

\section{Table 1 About Here}

Because the idealization of leaders, in this vision, is emotionally and normatively charged, it can inform contemporary discussions of the emotional and moral influences exerted by leaders. For example, while Erez et al. (2008) establish an empirical correlation between leader and follower affect, neglecting psychodynamic explanations leaves their findings to be explained through cognitive mimicry (e.g. Barsade, 2002; Bartel \& Saavedra, 2000). But if, as described above, we frame leadership schema as arising from internalized authority roles, then affect transfer becomes understood as the vicarious pleasure experienced 
by followers via the introjected authority figure. From a psychoanalytic perspective, emotional mimicry makes sense because the possibility of emotional self-expression ultimately depends on the possibilities for identity provided by symbolic authority structures.

From the point of view of idealization, furthermore, identification with leaders is normatively loaded, and a psychological theory of leadership categorization should give some account of how individuals deal with the normative demands of identity. The ego dynamics resulting from the narcissistic stages (Freud, 1914) ground a normative account because the ego-constitutive steps describe above are essentially attempts to return to an imagined original state. These origins are imagined as a utopian beginning and ending point, and cognition itself is simply the working out of a labyrinth whose goal is to reach this imaginary point.

Seen in this light, all cognition contains a normative element, since it is oriented towards an idealized origin, constructing schematic structures to represent this ideal while by this very construction blocking its goal. These structures may be automatic, as in the almost thoughtless submission to the ideal ego, the figure of the superstar or world-changing leader. They may be rigidly stereotypical, as in the super-egoic internalization of a leader-type which is rigidly applied according to consistent criteria. Or they may be reflective, contemplative and ambitious, as in an individual's earnest attempt to create a self-project by emulating a mentor, who comes to stand for the ego-ideal. In each case, the decision to be made is thoroughly normative, for it responds to the fundamental question "How should a person be"? In order to deal with this foundational question, leadership theory can benefit from an engagement with psychoanalysis.

What could such an engagement look like, in terms of the empirical study of leadership? For example, while we know that self-concepts are linked to memory (Greenwald \& Banaji, 1989) and nostalgia (Gebauer, Broemer, Haddock \& von Hecker, 2008), the idea of linking leader identification with nostalgia would not make sense via a simple categorization 
mechanism. However, we know that leaders often use a rhetoric of memory and nostalgia to mobilize followers (e.g. Parry-Giles \& Parry-Giles, 2000). Viewing leader perceptions as projections of a nostalgia-driven ego would allow such observed phenomena to linked with follower perceptions of leaders.

The Self as Divided and Relational

As mentioned above, SIT-L emphasizes leader fit within follower self-schemas, rather than fit with leadership schemas, focusing on the link between self-identity and leadership. While LCT treats cognitive prototypes as individual information processing categories (Fielding \& Hogg, 1997), SIT-L focuses on group categories, which from the social bases of identity formation, (Hogg 2001; Hogg \& Terry, 2000; Fielding \& Hogg, 1997).

While SIT-L converges with psychoanalysis in emphasizing the importance of identity to leadership cognitions, it frames identity very differently, leading the two approaches in fundamentally different directions. The principal difference lies in the motivational structure of identity, which differs across the two approaches. Two important theoretical divergences result from this difference in emphasis.

First, SIT-L holds that leaders emerge from follower identifications. While contemporary perspectives recognize the presence of multiple self-schemas (e.g. Shower \& Zeigler-Hill, 2003; Shamir, House \& Arthur, 1993; Markus \& Wurf, 1987), self-schemas tend to be seen as internally consistent cognitive structures (Khilstrom \& Klein, 1994). Because the internal cohesiveness of self-identities is often taken for granted, identity becomes equivalent to similarity, such that leaders emerge who are similar to the prototypical selfidentities of followers (Hogg, 2001, 2005; Hogg \& van Knippenberg, 2003). The social categories discussed usually represent traditional social groupings (e.g. gender, ethnic, or other social groupings), and the questions remain of a.) How particular social prototypes 
become appropriated and internalized or b.) Why this should happen in the first place, other than the general cognitive motive of uncertainty reduction (e.g. Hogg 2001).

By contrast, the problem of the establishment of an identity out of the myriad pieces of the social world is the defining problem of psychoanalysis (Schroeder \& Carlson, 2007). In most psychoanalytic views, the self is inherently split, that is, because the ego-ideal is a symptom of the fractured nature of the self (i.e. the drive toward a lost sense of unity), it is not possible to equate identification with sameness in psychoanalysis. Rather, identification involves the projection of a self-ideal onto another, which simultaneously produces identification and self-alienation.

This difference is important for thinking about identification with leaders because, while both perspectives stress identification, the differing views of identity lead to quite different conclusions. In psychoanalysis, identification brings with it alienation, the fact of seeing oneself (or one's self-ideal) as outside of oneself, and thus combines identity with a sense of lack. It is this lack that creates the desire associated with emulating an authority figure, a desire which is difficult to explain as long as the self remains whole in the process of identification.

As a consequence, in SIT-L, identification with a leader should be linearly related to positive relation between follower and leader, while differentiation should lead to an antagonistic relationship. For example, Hogg \& Terry (2000) distinguish between selfcategorization based leadership and leadership based on structural or formal differentiation, a distinction which they use to contrast virtuous and abusive leadership. In psychoanalysis, however, this distinction breaks down, given the fact that complete identification would destroy the leader-follower bond, since the difference giving rise to the ideal relation would be erased. To fully identify with the leader, in other words, would risk destroying the distinction between self and other that formed the basis for identification itself. It is the subtle 
interplay between identification and alienation that establishes the charismatic myth, framing the leader as an improved version of the self, or what the self would look like were it to become fully realized. In this respect, charismatic and identity views of leadership are complementary from the point of view of psychoanalysis, and both describe the vicissitudes of the split subject in search of him/herself.

This point has important implications for the way we study follower-based views, because the idealization implicit in charismatic, romanticized views of leadership might seem at odds with a self-matching view, that stresses similarity rather than "greatness" in a leader. However, by taking psychoanalysis seriously we can understand, for example, why selfempowerment results from transformational leadership (Kark, Shamir \& Chen, 2003), a finding that would seem strange if the self and other were seen as opposing. Additionally, new research avenues would be opened into the apparent paradox that identification (from a cognitive perspective) seems to imply a flattening of hierarchical relationships, while leader idealization may imply the opposite. Allowing identity to be conceptualized as an idealized projection would provide a way to explain how varying effects could be the outcomes of similar leader-follower relations.

Second, and relatedly, the SIT-L view of identity as coherent and unified reflects its origins in the cognitive psychology tradition. Indeed, Tajfel's (e.g. 1969) early work was in the Gestalt tradition, which focused on the cognitive treatment of figures and wholes. This cognitive bent may explain the underplaying of the normative bases of social cognition. For example, key to SIT-L is the idea that liking and complying with leaders is a function of their self-prototypicality (Hogg, 2001, 2005). Leadership is a function of liking, which is in turn a function of both salience and similarity (Hogg, 2001). Leaders that match self-prototypes are more likely to benefit from cognitive heuristics because they appear perceptually distinctive (e.g. figural against a background) or cognitively salient (Hogg, 2005, p. 60). In addition, 
because people tend to exhibit greater liking for people similar to them, self-prototypical leaders will be more liked, and this will lead to leader-follower alignment in the organization. The motivational drive for these effects is the reduction of cognitive uncertainty (Hogg, 2001).

Very differently from identification in psychoanalysis, which is a guilt-ridden and traumatic process, in SIT-L identification is largely descriptive and sanitized of inner struggles. The psychoanalytic ego does not only recognize itself in the identified object, but strives toward self-realization through it. What is at stake is not simply the reduction of uncertainty, a primarily cognitive process, but rather the narcissistic struggle by the follower to achieve an ideal, a thoroughly normative picture of the self that is absent from the prototype discussion. While SIT does not deny this libidinal push toward an ideal (e.g. Tajfel and Turner, 1979), it does tend to marginalize questions of self-worth, missing the moral striving dimension involved in the formation of identity.

In short, SIT-L, in the tradition of social cognition (e.g. Fiske \& Taylor, 1991), views the subject in self-categorical terms, with individuals possessing self-schema and motivations to positive self-views. Psychoanalysis, on the other hand, holds a dynamic view of the subject, in which an inarticulable and hidden subject struggles to express itself by constructing narcissistic identities which never quite fit. By not getting behind the traumatic origins of self-identities, SIT-L loses the important insight that self-schemas always hide the subject in and through the very act of embodying the subject. Thus, ego defense mechanisms come to appear as similarity-liking biases, and we can no longer see the existential struggle underlying authority relations.

The Disappearance of the Super-ego

One consequence of the cognitive simplification of self-leader relations is the disappearance of the equivalent of the super-ego in mainstream leadership research. The 
super-ego function simply no longer makes sense once the self-alienation and objectification involved in identification is no longer theorized. This self-objectification, while present in the ideal ego (as nostalgic longing) and the ego-ideal (as imaginary self-image), it is most acutely felt in the super-ego function, which involves actively submitting oneself to unrelenting judgment.

The disappearance of a super-ego function in leadership theory seems odd, since this area deals inherently with issues of power relations, and the super-ego relies on internalized power relations (Freud, 1933). Indeed, several organizational scholars outside the leadership tradition have viewed the norms of an organization as essentially related to Oedipal processes involved with the super-ego (e.g. Arnaud, 2002; Long; 1991; Styhre, 2008). The absence of the super-ego is apparent in both leader-centered views and in follower-centered views. For example, the neo-charismatic construct of transformational leadership (e.g. Burns, 1978; Bass, 1985) emphasizes follower empowerment and moral uplift. For abusive, punishing, or immoral leadership, Bass retains the label "pseudotransformational leadership" (Bass, 1999, 1993), but does not theorize how the punishing action is internalized by followers.

Follower-centric views such as LCT likewise disregard normative notions such as the super-ego, treating leader schemas similarly to other cognitive categories (e.g. Greenwald \& Banaji, 1989). Yet, it is hard to imagine a leadership prototype not involving normative judgments or normative self-comparisons. Similarly, with regards to SCT-L, it is difficult to imagine following a leader because that leader embodies one's cognitive self-prototype without judging the leader and oneself normatively in terms of that prototype. And if one's leader is more self-prototypical than oneself, then it is likely that the subject will feel awe (ideal ego), ambition (ego-ideal) or self-loathing (super-ego) as a result.

With regards to normativity, psychoanalytically informed views within and outside the leadership literature, which place issues of punishment as foundational to identity 
development, have historically explored the sadistic and tyrannical side of leadership (e.g. Goethals, 2005; Kets de Vries, 2006; Stein, 2007). For example, Stein (2007) describes how unresolved Oedipal issues may have been at the heart of the Enron scandal, and Kets de Vries $(2006 ; 2004)$ has recently explored the psychological bases of despotic leadership. With regards to leadership perceptions, Goethals (2005) reminds us that according to Freud, authority figures are not only seen as charismatic, but also as dangerous and threatening, leading to ambivalent feelings by followers that are difficult to explain with prototype-based theories. This focus on the moral ambivalence of leadership facilitates psychoanalytic approaches in important contemporary issues such as corporate corruption (e.g. Stein, 2007), worker precariousness (e.g. Deranty, 2008), and crisis management (e.g. Stein, 2004). Recuperating the notion of the super-ego provides inroads into explaining how the dark side of leadership may be built into the very concept of leadership, rather than as a marginal aberration.

In this vein, the study of abusive leadership from a psychoanalytic lens allows formerly diverse strands of empirical research to tell a more coherent story than is currently the case. For example, while the empirical literature on power (for a review Keltner, Gruenfeld \& Anderson, 2003), documents the links between power and potentially abusive behaviors, these are framed in terms of resource acquisition and increased behavioral disinhibition, and are treated as dysfunctional aspects of power holders. However, acknowledging something similar to a super-egoic identity function would allow such behaviors to be seen as the systemic ambivalence in leadership between identification and alienation, which leads to aggressive behaviors of domination. Understood thus, for example, we would be able to better understand the compliance of followers faced with such leaders, beyond a simple material dependence perspective, and thus better understand the symbolic bases of leadership. 


\section{Theoretical Implications}

I have attempted to demonstrate how follower-based cognitive approaches in leadership theory can be expanded through dialogue with psychoanalysis. It was my objective to show how these approaches have progressively demonstrated the importance of self-processes in leadership, but have done so largely independently of psychoanalysis. However, the very cognitive turn that has produced interesting results in this literature has also occluded the dynamics between self and authority that make leadership an interesting field of study (Beyer, 1999). In this section, I will attempt to summarize some of the theoretical extensions that maintaining a dialogue with psychoanalysis can offer to future research.

First, while from a socio-cognitive perspective, leadership categorization and identity perspectives seem like clearly distinct theories (e.g. Hogg, 2001), from a psychoanalytic perspective, they seem complementary and mutually reinforcing. Because identity in the latter involves the active construction of an ego-identity on the basis of internalized authority figures, there may be a closer link between leadership schema and self-schema than is apparent from socio-cognitive views. Linking identity to a powerful other in order to achieve drive satisfaction, in this view, is always unsuccessful because the very act of identification is here a kind of self-alienation, which paradoxically increases the motivation for identity consolidation. To understand this dynamic process, however, it is necessary to recognize the psychoanalytic notion of a divided self, a neglected aspect of contemporary socio-cognitive perspectives.

Extending the previous point, the ambivalent nature of identity adds to a psychological literature that, despite what was asserted above, has also become increasingly open to viewing the self as multifaceted (e.g. Shower \& Zeigler-Hill, 2003; Shamir, House \& Arthur, 1993; 
Markus \& Wurf, 1987). More precisely, within the socio-cognitive tradition, views of multiple self-identities (e.g. Withers, Corley \& Hillman, 2011), of identity priming and salience effects (van Knippenberg, van Knippenberg, Cremer \& Hogg, 2004), and of contradictory identities (e.g. Cooper \& Thatcher, 2010) have emerged; however, none of these perspectives recognize ambivalence as a constitutive feature of identity per se, in the way that psychoanalysis does (e.g. Arnaud, 1998). In other words, from a psychoanalytic view of identity, it is not simply that individuals can have multiple or contradictory self-identity schemas, but rather that the creation of self-identity is itself fraught with contradictions, because it means crafting a self out of materials found on the outside, a form of selfobjectification that is internally paradoxical. This tension gives identity its powerful motivational and relational force, and thus is important to recognize in an identity view of leadership.

Relatedly, as discussed above, psychoanalytic perspectives reinstate self-based views of leadership as a morally relevant, dealing with ideals and normative exigencies rather than simply categorization and uncertainty reduction. This observation constitutes one of the most interesting aspects of leadership as a phenomenon, that it resides in the interstices of the descriptive and the normative. Leadership is not purely descriptive because being a leader is not equivalent to holding power or exerting influence, but involves an ideal vision for followers. It is not purely moralistic because simply being morally admirable is not sufficient for effective leadership. The re-introduction of the super-ego as a moralizing psychological function is one way in which leadership can draw on psychoanalysis to understand its moral authority. The current paper takes one step towards reopening the discussion in this direction.

Nevertheless, some difficult questions follow from adopting psychoanalytically-based views about leaders and followers. If, as I have claimed, identification involves a hierarchical projection of authoritative others by a fundamentally ambivalent self, how does identification 
with leaders combine with an ethic of liberal democracy that posits formal equality among persons? Is, for example, a psychoanalytic view of leadership consistent with liberal ideas about human dignity and worth? Can we re-insert notions of the ego-ideal or super-ego into our view of persons and still hold on to the intrinsic self-sanctity of the liberal subject? Seen in this light, the dialogue between unified self-views views in social psychology and psychoanalytic views over the self may reflect struggles over how to cleave together the sanctity of the self with an ethic of leadership. Social psychology has brought leaders down to earth by making them prototypes of everyday social groups. Can psychoanalysis reinsert notions of authority, guilt, and self-separateness without radically undermining notions of democratic leadership? The richness and importance of such a dialogue offers many possibilities for the future of leadership studies.

Finally, psychoanalytic views of the self help unify leader and follower-centered approaches. Because both leader and follower roles arise in the interpersonal dynamic, leader and follower centered views are not mutually exclusive when the focus is on this dynamic. In this respect, psychoanalysis follows views such as leader-member exchange (LMX) theory; however, the relational aspect in psychoanalysis goes deeper to explore how the very roles involved of the exchange are constituted in and through their relations. The leader stands in for the archaic sense of authority that arose during ego development, gaining a seemingly unexplainable power from this position, and the followers can gain a sense of stability and vicarious enjoyment from this authority.

Notwithstanding the above points, there are lacunas within a psychoanalytic approach to leadership that call for future clarification. For instance, a key question is that of how symbolic authority structures at work become internalized in individual identity structures, and why certain elements of a person's surroundings undergo this internalization while others do not. Research in this area would examine, for example, how certain leadership processes 
can promote relatively unconscious ideal egoic follower support, versus the more selfconscious ego-ideal identification, versus the hypercritical super-egoic leadership internalization, and how such differences affect workplace dynamics.

Additionally, while recent psychoanalytic work has conceived of identification as internalization of social meanings (e.g. Arnaud, 2002), and has stressed focusing on group (e.g. Goethals, 2005), organization, and system (e.g. Fotaki, 2006) levels of analysis there remains a need to unpack the relation between the symbolic macro-structure and the figure of the individual leader. Under what circumstances do authority structures become condensed into single individuals, and how does the institutional authority of social symbols differ from the personal authority of a powerful leader?

Finally, while the current paper groups "psychoanalytic approaches" rather broadly, it should be stressed that this is done for heuristic value, and that psychoanalysis englobes a wide range of traditions, rather than a common set of theoretical premises. By staying relatively close to Freudian views, the current paper makes specific points regarding the constitution of identity, while avoiding entanglements in the many internal debates within psychoanalysis. I believe that a general approach is most appropriate for the current paper's objectives; however it should be remembered that psychoanalysis is not a one-size-fits all approach.

Nevertheless, the current paper opens research agendas that extend themes already present under the surface of contemporary leadership theory. In short, although psychoanalysis has been present in leadership thought, it has remained largely outside of dialogue with other traditions. The current moment, I have argued, is ripe for an integration of psychoanalytic ideas into the mainstream of leadership studies.

\section{References}

Albert, S., \& Whetten, D. A. (1985). Organizational identity. Research in Organizational 
Behavior, 7, 263-295.

Arnaud, G. (2002). The organization and the symbolic: organizational dynamics viewed from a Lacanian perspective. Human Relations, 55(6): 691-716.

Arnaud, G. (1998). The obscure object of demand in consultancy : a psychoanalytic perspective. Journal of Managerial Psychology, 13(7), 469-484.

Agle, B. R., Nagarajan, N. J., Sonnenfeld. J. A. and Srinivasan, D. (2006). Does CEO charisma matter? An empirical analysis of the relationships among organizational performance, environmental uncertainty, and top management team perceptions of CEO charisma. Academy of Management Journal 49 (1): 161-174.

Arjoon, S. (2008). Reconciling situational social psychology with virtue ethics. International Journal of Management Reviews, 10(3), 221-243.

Barsade, S. G. (2002). The ripple effect: Emotional contagion and its influence on group behavior. Administrative Science Quarterly, 47: 644-675.

Bartel, C.A., and R. Saavedra, (2000). The collective construction of workgroup moods. Administrative Science Quarterly, 45: 197-231.

Bass, B. M. (1999). On the taming of charisma: A reply to Janice Beyer. Leadership Quarterly 10(4): 541-553.

Bass, B. M.(1985). Leadership and performance beyond expectations. New York Free Press.

Bass, B. M. and B. J. Avolio (1993). Transformational leadership: A response to critiques. In Leader theory and research: Perspectives and directions. M. M. Chemers and R. Ayman (eds.), 49-80. New York: Academic Press.

Beer, J. S., \& Keltner, D. (2004). What Is Unique About Self-Conscious Emotions? Psychological Inquiry, 15(2).

Beyer, J. M. (1999). Taming and promoting charisma to change organizations Leadership Quarterly 10(4): 307-330. 
Bion, W. R. (1961) Experiences in Groups. Tavistock.

Blos, P. (1985). Son and father. New York: The Free Press.

Bono, J. E., and R.Ilies (2006). Charisma, positive emotions, and mood contagion. Leadership Quarterly 17: 317-334.

Burns, J. M. (1978). Leadership. New York: Harper and Row.

Carr, A. N. and C. A. Lapp (2005). Falling in love with investments: A psychoanalytic review of the death instinct in critical management of organizational relationships. 4th International Critical Management Studies Conference, 4 - 6th July 2005, Cambridge University, UK.

Chasseguet-Smirgel, J. (1985). The ego-ideal: A psychoanalytic essay on the malady of the ideal. New York: Norton.

Cluley, Robert (2008) 'The Psychoanalytic Relationship between Leaders and Folllowers', Leadership, 4(2), 201-212

Cooper, D. \& Tatcher, S. (2010). Identification in organizations: The role of self-concept orientations and identification motives. The Academy of Management Review, 35(4), 516-538.

Diamond, M. and S. Allcorn (2003). The cornerstone of psychoanalytic organizational analysis: Psychological reality, transference and countertransference in the workplace. Human Relations 56: 491-514.

Erez, A., V. F. Misangyi, D.E. Johnson, M. A. LePine and K.C. Halverson (2008). Stirring he hearts of followers: Charismatic leadership as the transferral of affect. Journal of Applied Psychology 93(3): 602-616.

Fielding, K. S., and M. A. Hogg (1997). Social identity, self-categorization, and leadership: A field study of small interactive groups. Group Dynamics: Theory, Research, and Practice, 1: 39-51. 
Fiol, M. C., Harris, D. \& House, R. (1999). Charismatic leadership: Strategies for effecting social change. Leadership Quarterly. 10, 449-482.

Fiske, S.T., and S. E. Taylor (1991) Social cognition (2nd ed.). New York: McGraw-Hill.

Fotaki, M. (2006). The Choice is yours: A psychodynamic exploration of health policymaking and its consequences for the English National Health Service. Human Relations, 59, 12, 1711-1744.

Foti, R. J., Fraser, S. L. \& Lord R. G. (1982) Effects of Leadership Labels and Prototypes on Perceptions of Political Leaders. Journal of Applied Psychology, 67, 326-333.

Freud, S. (1905). Three essays on the theory of sexuality. In The standard edition of the complete works of Sigmund Freud, vol. 7: 123-243. London: Hogarth Press.

Freud, S. (1914). On narcissism: An introduction. In The standard edition of the complete works of Sigmund Freud, vol. 14: 67-102. London: Hogarth Press.

Freud, S. (1921). Group psychology and the analysis of the ego. In The standard edition of the complete works of Sigmund Freud, vol. 28: 65-143. London: Hogarth Press.

Freud, S. (1923). The ego and the id in The standard edition of the complete works of Sigmund Freud, vol. 19: 1-66. London: Hogarth Press.

Freud, S. (1933). New introductory lectures on psycho-analysis. In The standard edition of the complete works of Sigmund Freud, vol. 22: 1-82. London: Hogarth Press.

Freud, S. (1965). Totem and taboo. In The Pelican Freud Library, vol. 13, Penguin Books: Harmondsworth. [Original published 1912-13.]

Gebauer, J. E., Broemer, P., Haddock, G., \& von Hecker, U. (2008). Inclusion-exclusion of positive and negative past selves: mood congruence as information. Journal of personality and social psychology, 95(2), 470-87. 
Goethals, G. R. (2005). The psychodynamics of leadership: Freud's insights and their vicissitudes. In D. M. Messick and R. M. Kramer, (Eds.), The Psychology of

Leadership: New Perspectives and Research (pp. 97-112). Mahwah, New Jersey: Lawrence Erlbaum Associates.

Graen, G. B. (2007). Asking the wrong questions about leadership. American Psychologist 62(6): 604-605.

Graen, G.B., and M.Uhl-Bien (1995). Relationship-based approach to leadership: Development of leader-member exchange (LMX) theory of leadership over 25 years: Applying a multi-level multi-domain perspective. Leadership Quarterly 6: 219-247.

Greenwald, A. G. and M.R.Banaji (1989). The Self as a memory system: Powerful, but ordinary. Journal of Personality and Social Psychology 5(1): 41-54.

Haidt, J. (2001). The emotional dog and its rational tail. Psychological Review 108: 814-834.

Hogg, M. A. (2005). Social Identity and leadership. In The psychology of leadership: New perspectives and research. D. M. Messick and R. M. Kramer (eds.) 53-80. Mahwah, New Jersey: Lawrence Erlbaum.

Hogg, M. A. (2001). A social identity theory of leadership. Personality and Social sychology Review 5: 184-200.

Hogg, M. A., and Terry, D. J. (2000). Social identity and self-categorization processes in organizational contexts. Academy of Management Review 25: 121-140.

Hogg, M. A. and D. van Knippenberg (2003). Social identity and leadership processes in groups. In Advances in experimental social psychology. M. P. Zanna (ed) vol. 35, 152. San Diego, CA: Academic Press.

House, R.J. and M. L. Baetz (1979). Leadership: Some empirical generalizations and new research directions in B. M. Staw (ed), Research in organizational behavior 341-423. Greenwich, CT: JAI Press. 
Judge, T. A., J.E. Bono, R. Ilies, and M.W. Gerhardt (2002). Personality and leadership: A qualitative and quantitative review. Journal of Applied Psychology 87: 765-780.

Kark, R., Shamir, B., \& Chen, G. (2003). The two faces of transformational leadership: Empowerment and dependency. Journal of Applied Psychology, 88, 246-255.

Keltner, D., Gruenfeld, D., \& Anderson, C. (2003). Power, approach, and inhibition. Psychological Review, 110, 265-284.

Kets de Vries, M.F.R. (2006). The spirit of despotism: Understanding the tyrant within. Human Relations 59(2): 195-220.

Kets de Vries, M.F.R. (2004). Lessons on leadership by terror: Finding Shaka Zulu in the attic. Cheltenham: Edward Elger.

Kets de Vries, M.F.R. (1989). Prisoners of leadership. New York : Wiley

Kets de Vries, M.F.R. and D. Miller. (1985). The neurotic organization. San Francisco: Jossey-Bass.

Kets de Vries, M., \& Miller, D. (1985). Narcissism and leadership: An object relations perspective. Human Relations, 38, 583-601.

Kihlstrom, J. F., Beer, J. S., \& Klein, S. B. (2003). Self and identity as memory. In M. R. Leary, \& J. P. Tangney (Eds.), Handbook of self and identity (pp. 68-90). New York: The Guilford Press.

Kihlstrom, J. F., \& Klein, S. B. (1994). The self as a knowledge structure. In R. S. Wyer, Jr., \& T. K. Srull (Eds.), Handbook of social cognition (2nd ed.) Hillsdale, NJ: Lawrence Erlbaum Associates.

Lagache, D. (1961). La psychanalyse et la structure de la personnalite. In Oeuvres IV, 19561962. Paris: Presses Universitaires de France.

Long, S. (1991). The signifier and the group. Human Relations 44(4): 389-401.

Lord, R.G. (1977). Functional leadership behavior: Measurement and relations to social 
power and leadership perceptions. Administrative Science Quarterly 22: 114-133.

Lord, R. G. (1985). An information processing approach to social perception, leadership and behavioral measurement in organizations. Research in Organizational Behavior 7: 87128.

Lord, R.G. and D. J. Brown (2004). Leadership processes and follower self-identity. New Jersey: Lawrence Erlbaum. Lord, R.G. and D. J. Brown. 2001. Leadership, values, and subordinate self-concepts. Leadership Quarterly 12: 133-152.

Lord, R.G. ,D. J. Brown and J. L. Harvey (2001). System constraints on leadership perceptions, behavior and influence: An example of connectionist level processes. In Blackwell handbook of social psychology: Group processes. M. A. Hogg and R. S. Tindale (eds), 283-310. Oxford, England: Blackwell.

Lord, R.G., Foti R.J. and Phillips, J.S. (1982). A theory of leadership categorization. In J.G. Hunt, U. Sekeran and C. Schriesheim, Eds., Leadership: Beyond Establishment Views, pp 104-121. Southern Illinois University, Carbondale.

Lord, R.G., R. J. Foti and C. L. DeVader (1984). A test of leadership categorization theory: Internal structure, information processing, and leadership perceptions. Organizational Behavior and Human Performance, 34: 343-378.

Lord, R. G. and K.J. Maher (1991). Leadership and information processing: Linking perceptions and performance. Boston: Unwin-Hyman.

Lord, R.G., C. De Vader and G.M. Alliger (1986). A meta-analysis of the relation between personality traits and leadership perceptions: An application of validity generalization procedures. Journal of Applied Psychology 71: 402-410.

Lowe, K. B., K. G. Kroeck and N. Sivasubramaniam (1996). Effectiveness correlates of transformational and transactional leadership: A Meta-analytic review of MLQ literature. Leadership Quarterly 7: 385-425. 
Markus, H. R., \& Wurf, E. (1987). The dynamic self concept: A social psychological perspective. Annual Review of Psychology, 38, 299-337.

Mijolla-Mellor, S. (2005). Ego-ideal/ideal ego in The International dictionary of psychoanalysis. Farmington Hills, MI: Thompson-Gale.

Meindl, J. R. (1993). Reinventing leadership: A radical, social psychological approach. In Social psychology in organizations: Advances in theory and research . J. K. Murnigham (ed) 89-118.Engelwood Cliffs, NJ: Prentice Hall.

Nye, J. L. and D. R. Forsyth (1991). The effects of prototype-based biases on leadership appraisals: A test of leadership categorization theory. Small Group Research 22: 360379.

OReilly, C. III and J. Chatman (1986). Organizational Commitment and Psychological Attachment: The Effects of Compliance, Identification, and Internalization on Prosocial Behavior. Journal of Applied Psychology 71(3): 492-499.

Parry-Giles, S. J., \& Parry-Giles, T. (2000). Collective memory, political nostalgia, and the rhetorical presidency: Bill Clinton's commemoration of the March on Washington, August 28, 1998. Quarterly Journal of Speech, 86(4), 417-437.

Pfeffer, J. (1981). Management as symbolic action: The creation and maintenance of organizational paradigms. Research in organizational behavior, 31, 1-52.

Schroeder, J.L. and D. G. Carlson (2007). Psychoanalysis as the Jurisprudence of Freedom. Cardozo Legal Studies Research Paper No. 200. Available at SSRN: http://ssrn.com/abstract $=1011175$

Schwartz, H. S. (2002). Political correctness and organizational nihilism. Human Relations 55(11): $1275-1294$.

Schwartz, H.S. (1990). Narcissistic processes and corporate decay: The theory of the 
organization ideal. New York: New York University Press.

Shamir, B., House, R. J., \& Arthur, M. B. (1993). The motivational effects of charismatic leadership: A selfconcept based theory. Organizational Science, 4, 577-594.

Stein, M. (2007). Oedipus Rex at Enron: Leadership, Oedipal struggles, and organizational collapse. Human Relations 60(9): 1387-1410.

Stogdill, R.M. (1948). Personal factors associated with leadership: A survey of the literature. Journal of Psychology 25: 35-71.

Styhre, A. (2008). Management Control in Bureaucratic and Postbureaucratic Organizations. Group and Organization Management 33(6): 635-656.

Summers, F. (2005). The Self and Analytic Technique. Psychoanalytic Psychology, 22(3), 341-356.

Tajfel, H. (1969). Cognitive aspects of prejudice. Journal of Social Issues 25: 79-97.

Tajfel, H. and J.C.Turner (1979). An integrative theory of intergroup conflict. In The social psychology of intergroup relations. W. G. Austin and S. Worchel (eds) 33-47. Monterey, CA: Brooks/Cole.

Turner, J.C. (1985). Social categorization and the self-concept: A social cognitive theory of group behavior. In Advances in group processes: Theory and research, vol 2. E. J. Lawler (ed) 77-122. Greenwich, CT: JAI.

Tyler, T.R., and A.E. Lind (1992). A relational model of authority in groups. In Advances in experimental social psychology, vol 25. M. P. Zanna (ed.) 115-191. New York: Academic Press.

van Knippenberg, D., van Knippenberg, B., De Cremer, D., \& Hogg, M. A. (2004). Leadership, self, and identity: A review and research agenda. The Leadership Quarterly, 15, 825-856.

Weber, M. (1947). The theory of social and economic organization. A.M. Henderson, T. 
Parsons (trans.) and T. Parsons (eds, original work published 1922). NY: Free

Press.

Withers, M. C., Corley, K. G., \& Hillman, A. J. (2011). Stay or Leave: Director Identities and

Voluntary Exit from the Board During Organizational Crisis. Organization Science, 1-16.

Zaccaro, S. J. (2007). Trait-based perspectives of leadership. American Psychologist, 62(1), 6-

16.

\footnotetext{
${ }^{\mathrm{i}}$ As an attempt to introduce basic psychoanalytical ideas into the socio-cognitive leadership tradition, this paper deals mainly with relatively mainstream Freudian versions of psychoanalytic thought, with the important exception that the Freudian notion of ego is generally translated by "identity", mainly for ease of discussion. The wide diversity of psychoanalytic approaches, however, should be acknowledged, as well as the presence of derivations of "identity" approaches in psychoanalysis that resemble closely to contemporary cognitive views (c.f. Summer, 2005).
} 